\title{
Integrating Literary Works as the Local Content of ELT Materials for Undergraduate Students
}

\author{
${ }^{1}$ Pratiwi Amelia, ${ }^{2}$ Agci Hikmawati, \\ 1,2 STKIP Muhammadiyah Bangka Belitung, Indonesia \\ pratiwi.amelia@stkipmbb.ac.id
}

\begin{abstract}
The objective of this study is to design English materials for undergraduate students. In designing the materials, the writers focused on the general English materials integrated with Bangkanese' Folks as one of the literary works existing in Bangka Belitung Province, Indonesia. This idea was based on the writers' awareness to introduce local values to the students. Thus, the existing literary works were taken and modified by the writers to meet the purpose of the research. The writers used the theory of Hutchinson and Waters (1987) and Borg \& Gall (1989). The theory offered six steps, namely need analysis, writing syllabus, developing materials, trying-out materials, evaluating materials, revision, and writing the final draft. The participants of the research were 37 students studying in one of the private colleges in Bangka Belitung Province. These participants were chosen randomly. The designed ELT materials integrated the English lessons and the local folktales and culture. The integration was intended to improve the students' communicative competence of both productive and receptive skills. Furthermore, it was expected that the designed materials were able to encourage the students to communicate more communicatively and appropriately in their social context.
\end{abstract}

Keywords: designing materials, Bangkanese' folks, ELT

How to Cite: Amelia, P. and Hikmawati, A. (2019). Integrating Literary Works as the Local Content of ELT Materials for Undergraduate Students. English Language Teaching Educational Journal, 2(3), 133141.

\section{INTRODUCTION}

In Indonesia, English is treated as a foreign language (EFL). It means that Indonesians do not use English in their daily conversations. They only use English in particular condition, such as in the field of business, economy, education, and science. Among these fields, it is known that learning English for education is more popular and the most commonly used in Indonesia. Most of the students in Indonesia learn English in order to fulfil the academic demands from their school or university. As a result, the teacher as the main facilitator in the class should be able to build the knowledge and skills needed by the students in order to succeed their learning.

In teaching English as a foreign language, there are two kinds of skills learned; they are productive and receptive skills. Speaking and writing belong to productive skills, while reading and listening are categorized as receptive skills. Receptive skills refer to how people extract meanings from the discourse they see or hear, and this processing is called listening and reading. In addition to these two categorizations, students also need knowledge of language building and construction such as grammar, spelling, vocabulary, and phonics. This knowledge is required to make students be able to communicate effectively and appropriately, especially in constructing and making sentences. For this kind of case, teachers should make and use various and propriate methods, techniques, and materials to provide all the elements of language needed by the students. Appropriate and interesting lesson and materials will create students' curiosity and motivation in learning English. Thus, English teachers should be familiar with language use in order to develop 
their own skills and understand language as a social phenomenon and not merely as an exclusive learning branch, (Keshavarzi, 2012).

In relation to materials or course books, it's said that it's important to ensure that the course content needed for ready implementation is delivered in a consistent format. Research has found that appropriate language content motivates learners to develop language skills (Viswanath, 2019). It's due to the nature that language is associated with culture. That is, language is the carrier of cultural messages. One of the cultural forms is literature.

In a learning context, literature is considered very significant when it's employed in a language teaching and learning. Literature is a good source to teach English. Moreover, It has a particular context to contextualize the teaching activities (Keshavarzi, 2012). As a result, teachers can use many sources of liteary works as teaching materials. Wellek and Warren (1996) define literary work as a branch of literature which deals with any materials to create a picture, an idea or a story in a meaningful pattern. The literary work is also a work of art. It can be a drama, fiction, essay, biography, or journalism and so on. Literary works nowadays are more popular to use since it has many advantages in language teaching. Literary works such as poetries, novels, stories, or plays should be used in foreign language teaching because these works include all the features needed to teach a foreign language (Erdem, 2016). There are several types of literature that can be used for teaching purpose, as well as the approach to the use of literature in language teaching, and the underlying reasons for using literature in language teaching (Arafah, 2018).

In regard to teaching materials, Hutchinson and Waters (1987) wrote that there are three kinds of materials, namely materials evaluation, materials development, and material adaptation. As for teachers, they can evaluate from existing materials and then revise it, develop materials by the teacher, or modify the existing materials and then writing the materials. In ELT, The teacher can use literature to evaluate, to develop, or to adapt the material for the students, so the students will not get bored and be attracted to the materials.

\section{Why This Research?}

There are four reasons why this study is essential to be conducted. First, literary works will be able to make lessons enjoyable, to make the students learn wisdom and knowledge, and to increase the student's cultural awareness and moral values. Harmer (2001) says learning materials should attrack and raise the students' challenge to learn English, so the students would not feel bored during the lesson. Interesting materials in the classroom will raise the student's ability and motivate them to involve actively in the classroom. Second, the use of literary works in the ELT classroom as media or material in teaching and learning activity can give a chance for students to analyse, to critics, to evoke their feelings and thoughts creatively. Studying through literary works will raise the student's interest to study English. Third, the use of literary works will improve the students' awareness of their own culture. Fourth, teaching English through literature enhances the students' vocabulary mastery and reading comprehension (Ismail \& Masnur, 2019). Besides, it can promote literary understanding and general linguistic awareness among teachers and learners (Shazu, 2014; Yadav, 2014).

Most of the previous studies also found that the use of literature on language teaching has a positive influence on students' level of motivation and interest (Khodabakhshi \& Lagos, 1993; Goh, 1996; Estridge, 2000; Ho, 2000; Wu, 2001; Chen, 2006). Furthermore, more explicitly teaching English through folklore as part of literary works is such an 
effective strategy to promote and enable cross-cultural understanding because folklore can be found in everyday life (Gholson \& Stumph, 2005).

Literature enables the student's intercultural awareness to live, nurtures empathy, improves tolerance for diversity, and emotional intelligence (Ghosn, 2002). Unfortunately, not many students are aware of their local literature. Subhan (2006) claims that not all people like and love literature. Even many people have a terrible attitude toward literature. These people usually regard literature as something irrational or something useless. These facts show that there are people who do not like literature; even they said that reading literature is donkey work. However, there are so many works of literature that have rich content, yet they have not been explored adequately. Especially in Bangka Belitung Province, the condition is almost similar where there's not much attention paid to literary use in ELT. Another problem concerning English language teaching there is that there are no ELT materials which provide local content.

The problems in Bangka Belitung Province above is also occurring in at the one of the private colleges in Bangka Belitung, which was the setting of the research. Based on preliminary study conducted by the researchers, it was found out that many students were not aware of their own culture. Based on this identified problem, the researchers were eager to conduct a study to design ELT materials that integrated local content and ELT materials. It's hoped that it could expose the students to their own local culture while at the same time learning English effectively. With this, the students can get advantages of not only knowing about literature but also learning new vocabulary and phrases in order to improve their English ability. Thus, this study focuses on designing ELT materials by using Bangkanese' folks. This study presents the integration of literary works especially in teaching reading comprehension, speaking, writing, vocabulary, and grammar. It is hoped that the designed materials can In addition, the reserachers would like to promote the local content of Bangka Belitung to the students so that they will be more accessible and popular.

\section{RESEARCH METHOD}

This study aimed to develop an effective product that can be used in an educational program as the learning materials. According to Borg \& Gall (1983), Research and Development is a process to develop and validate education products. Products produced by $\mathrm{R} \& \mathrm{D}$ include teacher's training materials, learning materials, set of behavioural objectives, media, materials, management system and so on. Products are developed to meet specific needs and according to detailed specifications tested and revised until a specified level of the effectiveness is achieved. The product designed in this research was a set of English materials for undergraduate students by using literary works focusing on folktales. This study used local Bangkanese' folks which hasn't been explored yet in English teaching materials. The total participants in this study were 37 first semester students taken randomly from two departments of a private college in Bangka Belitung Province. The participants consisted of 20 students of Primary Education Department and 17 students of Sport Education Department. The instruments used in this study were two-phase of the questionnaire and interview, try-out, and group discussion with an expert senior lecturer. For the validity and reliability of the instruments, the researchers used the item validity to make sure that the instruments used were valid and reliable.

Several steps were conducted to meet the criteria of Research and Development (R\&D) research. The researchers followed Hutchinson \& Waters (1987) model in designing the research. The researchers implemented the seven steps to create an effective product. First, the researchers distributed a questionnaire for the need analysis. Second, the researchers analyzed and processed the questionnaires based on the students' need. Third, the researchers wrote a course grid and syllabus based on the result of the need analysis and 
designed the materials and activities based on the result of the needs analysis conducted previously. Fourth, the researchers conducted a try out by using designed materials and checked the validity and reliability of the material. Fifth, the researchers distributed the questionnaires to evaluate the designed material to the students. Sixth, the researchers analyzed and revised the designed materials based on the validation of the content and construct of the materials by using an expert judgment. Seventh, the researchers published the final draft.

\section{RESULTS AND DISCUSSION}

1. The Results of the Need Analysis

The results of the need analysis were taken from the distribution of the first phase questionnaire. The first questionnaires were distributed to the students to know the students needs, wants, and lacks. The questionnaire was also intended to be a guidance to design the materials in the latter step of the material designing process. Most of the students took parts in the study were female. It consisted of 25 female students, while male students were only 12 students. The age and the range of theirs varied. Most of them were in the range of 17-20 years old. The results of the need analysis were divided into two kinds of elements i.e. the students' knowledge level and the distribution based on the students' interest. The results of distribution of the students' needs are shown in the table below:

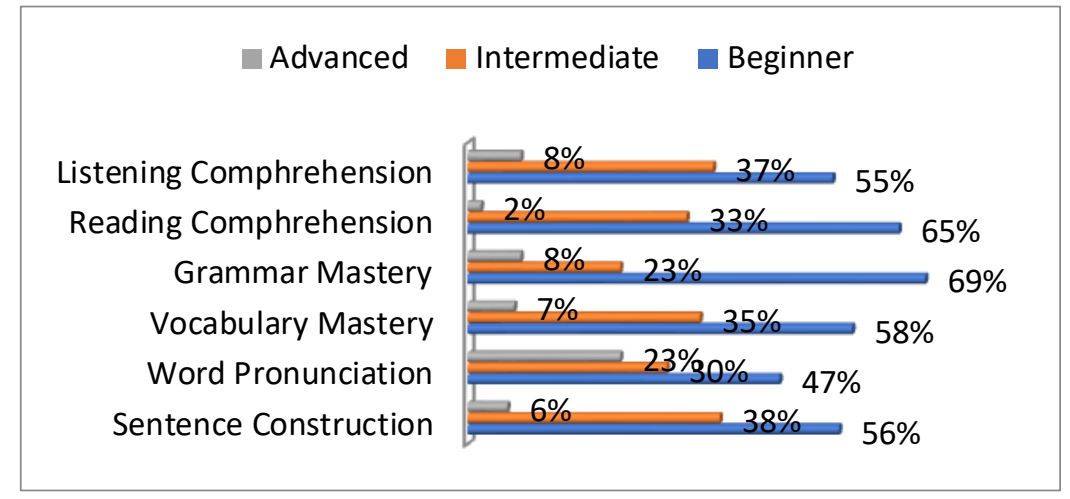

Figure 1. The Distribution of Students' Knowledge Level

Figure 1 shows the distributions of the students' knowledge level and also the students' lacks in learning English. It was divided into seven aspects, namely listening comprehension (beginner students were $55 \%$, intermediate students were 37\%, advanced students were $8 \%$ ), reading comprehension (beginner students were $65 \%$, intermediate students were $33 \%$, advanced students were $2 \%$ ), grammar mastery (beginner students were $69 \%$, intermediate students were $23 \%$, advanced students were $8 \%$ ), vocabulary mastery (beginner students were $58 \%$, intermediate students were $35 \%$, advanced students were $7 \%$ ), words pronunciation (beginner students were $47 \%$, intermediate students were $30 \%$, advanced students were 23\%), sentence constructions (beginner students were $56 \%$, intermediate students were $38 \%$, advanced students were $6 \%$ ). Based on the results, it can be concluded that most of the students have poor ability in English. 


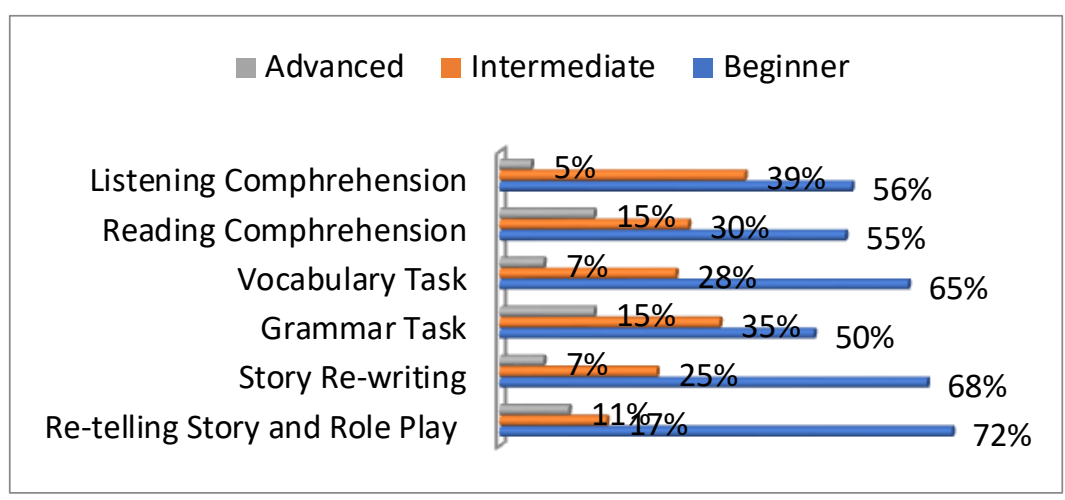

Figure 2. The Distributions of Learning Activity Based on the Students' Need

Figure 2 shows the distributions of students' needs on learning English. It was divided into six aspects covering listening comprehension (beginner students were $56 \%$, intermediate students were $39 \%$, advanced students were $5 \%$ ), reading comprehension (beginner students were $55 \%$, intermediate students were $30 \%$, advanced students were $15 \%$ ), vocabulary task (beginner students were $65 \%$, intermediate students were $28 \%$, advanced students were $7 \%$ ), grammar task (beginner students were $50 \%$, intermediate students were $35 \%$, advanced students were $15 \%$ ), story re-writing (beginner students were $68 \%$, intermediate students were $25 \%$, advanced students were $7 \%$ ), and role-play (beginner students were $72 \%$, intermediate students were $17 \%$, advanced students were $11 \%$ ). From this figure, it can be summed up that the students' needs on learning English varied. Based on these results, therefore, the writer tried to provide all the learning activities based on the results on Figure 2 during the step of material designing.

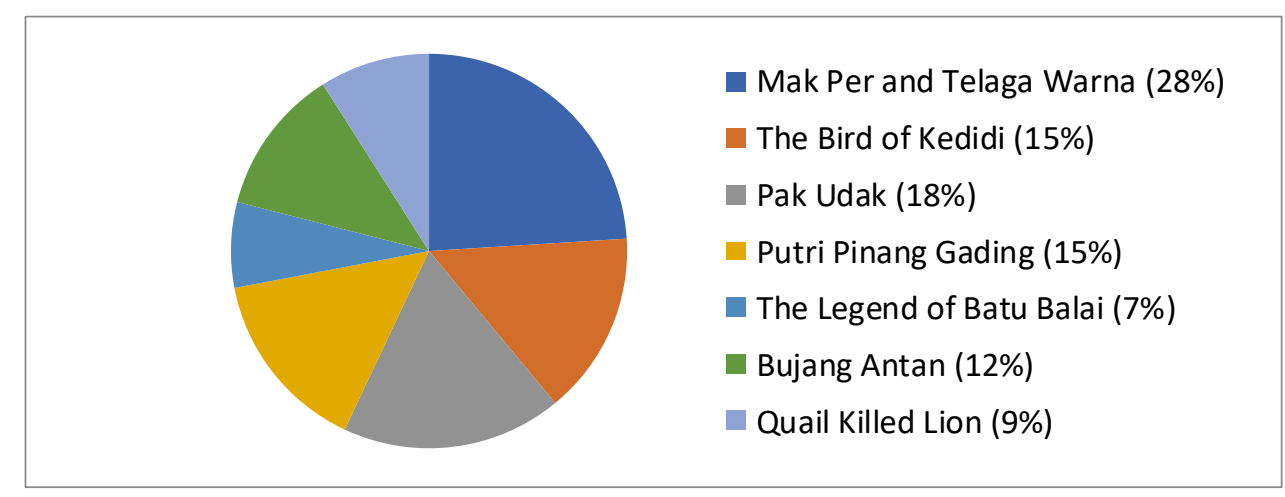

Figure 3. The Distributions of Students' Interest in Bangkanese' Folktales

From the distributions of the students' interest in Bangkanese' Folktales in Figure 3, it can be said that most of the students chose and were interested in Bangkanese' folktales. They also agreed that learning English through literary works would stimulate them to learn English more enjoyably. So, based on the results of need analysis on the kinds of Bangkanese' folktales chosen by the students, the researchers decided to include all the seven Bangkanese' folktales listed into the designed materials.

\section{Designing Materials}


The data taken from the questionnaire were used as a basis to design the ELT materials. The materials consisted of two parts. Each part consisted of warming up activities, vocabulary building, exercise, pronunciation practice, grammar rules, and conversation practice activities. The materials also covered all skills of English i.e. reading, writing, and speaking, and the language knowledge focused on grammar (simple past tense, past continuous, past perfect tense, past perfect continuous tense; temporal sequence; conjunctions), and vocabulary (action verbs). Each unit consisted of the learning goal and the main competence that should be achieved by the students after learning the materials. The sample of tasks presented in the designed materials are shown below:

a. Role Play

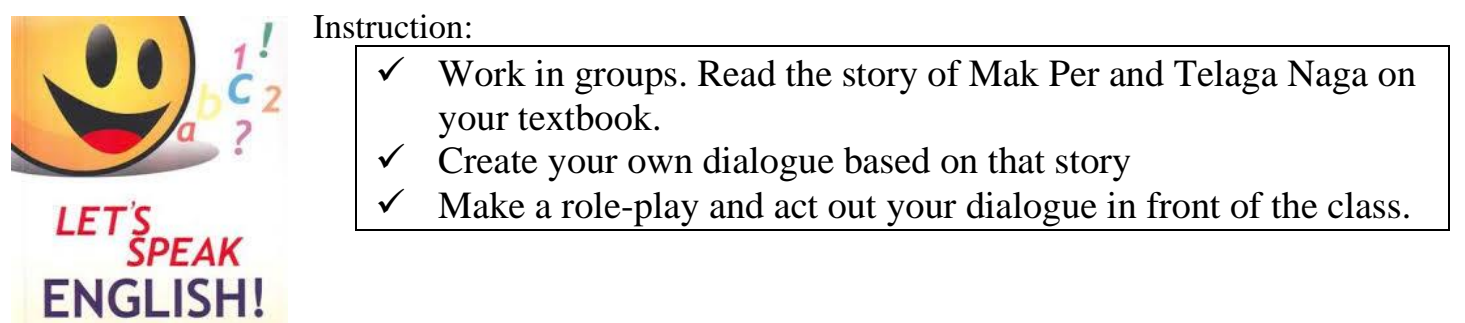

b. Re-write the story

Instruction: Re-write and complete this story based on your own imagination by using appropriate vocabulary and sentence constructions.

\section{Mak Per dan Telaga Naga}

One night, a grandmother said to his grandchild. "Bujang... Don't be naughty, please! A Naughty boy who played far away from home would be eaten by the dweller of Telaga Naga, said her. Your grandfather often told us about the Giant of Telaga Naga. I would tell you. Once upon a time, there was a bay in the coastal areas near Tempilang Village. The bay was Telaga Naga. A long ago, there was a giant living in this lake

c. Fill in the blanks

Instruction: Fill in the blanks and complete this passage by using appropriate vocabulary.

\section{Burung Kedidi}

In a village there lived two sons with their mother who was very old and she crooked. Their father died when they were still in their childhood age. Because they lived in suffering, one day they to leave their village. They asked their mother's to allow them.

"Mom, we wanted to sail over the sea and see the world. I wanted to change our life. I did not want it if we lived in suffering through all my life. Please, us to go", said the sons. 


\section{Try Out and Evaluation}

The try out was implemented to the 37 students of the setting of the research. These participants participated in the questionnaire filling previously held. The try out was conducted in 6 meetings. Based on the results of the try out, it can be summarized that the designed material has been appropriate and suitable for the students. Furthermore, an evaluation was needed to evaluate and validate the designed material. Thus, the content materials designed were evaluated and validated by a senior lecturer who was considered an expert in English language teaching. The results of the content validation were used to revise the designed materials.

It was also found out that, after the try out, the students were more interested in learning English. Most of them agreed that the use of literature could be used as one of techniques for teaching English for both language skills (i.e. reading, writing, listening and speaking) and language aspects (i.e. vocabulary, grammar and pronunciation). These results were in line with the research conducted by Hismanagolu, (2005) and the research conducted by Chen (2014) which claimed that literature could be effectively used to acquire English as a foreign language for students in all ages. Students got benefits from being challenged with language input that was slightly beyond their independent level of comprehension. Furthermore, Erdem (2016) stated that literature had a number of benefits, including, but not limited to the availability of unique material, stimulation of the reader's development and contribution to the reader's vocabulary and cultural enrichment. Along with the benefits mentioned, diversity, interest, vagueness, and universality could also be named as other advantages. Literature in language teaching materials should give students the opportunity to learn and use the language more creatively and to develop a better understanding of the language they are studying (Daskalovska \& Dimova, 2012).

Meanwhile, some researchers found the challenges in implementing the literary works into language teaching. Hasan (2019) stated that the language of literary works are difficult to understand, unfamiliar culture-related elements in the texts can be sources of difficulty in literature studies, and the problem with the genre. So, the teachers need to evaluate and consider the effectiveness of the literary texts use especially in terms of linguistic difficulty. Besides, need analysis is a mandatory pre-requisite before designing and producing any curriculum. So, it is important to consider the issues of context and culture before using it as a source of learning and designing appropriate exercises that best facilitate learning in the classroom. Thus, for teachers in using literature as learning materials, they should take into account the aspects of the learners' age, language level, clear learning objectives, appropriate pedagogically designed materials, and learning activities. The teachers should make sure whether the materials designed are suitable for the learners. Besides, the teachers should also consider the students' motivation, needs, and cultural background. Last but not least, one major factor to consider when using literature is whether a particular work is capable of revealing the kind of personal involvement by stimulating the interest of the learners and generating strong, positive reactions from them, (Hişmanağolu, 2005). To make it effective, the teachers need to evaluate, analyze, adapt, and modify the texts presents on the literary works before using it with the learners. Because not all literary works are suitable for teaching. It should meet the students' need and also it should match with the learning goal of learning. Otherwise, it will not be able to help the students in learning English and make it useless.

\section{CONCLUSION}

To sum up, the results of this study showed that developing English materials through local content integration were considered suitable for the intended students as showed through the results of try-out and evaluation done with the students and an expert in 
the fileld. The results of this study were in line with the previous study conducted by some researchers, who found out that literature can be used as an alternative way to teach English. Thus, it is essential to be creative in designing the materials by focusing on a particular field of study. However, not all the literature or literary works can be used as materials for teaching. The teachers need to select whether to make them suit the learners' age, English level, and syllabus appropriateness. That is why in designing ELT materials, teachers should follow the principlse of language teaching and materials development. The materials should be based on the needs of the students. Besides, the teachers have to pay attention to insert the cultural awareness and moral value when engaging the materials during the process of teaching and learning. By so doing, it would give the students a chance not only to know more about their culture but also to teach good character to the them. That is why the teachers nowadays should pay attention not only to the contexts of the materials but also how to teach a moral lesson to the students.

\section{REFERENCES}

Arafah, B. (2018). Incorporating the use of literature as an innovative technique for teaching English. Paper presented at the 1st Annual International Conference on Language and Literature. KnE Social Sciences. pages 24-36. doi:10.18502/kss.v3i4.1914

Borg. W. R., Gall, M. D. Gall (1983). Educational Research an Introduction. New York: Longman.

Chen, Y. M. (2006). Using children's literature for reading and writing stories. Asian EFL Journal, 8(4), 210-232. Retrieved from http://www.asian-efl-journal.com/

Chen, Mei-Ling. (2014). Teaching English as a foreign language through literature. Theory and Practice in Language Studies, 4(2), 232-236. doi:10.4304/tpls.4.2.232-236

Daskalovska. N., \& Dimova. V. (2012). Why should literature be used in the language classroom? Procedia - Social and Behavioral Sciences, 46, 1182 - 1186. doi: 10.1016/j.sbspro.2012.05.271

Estridge, P. G. (2000). Changing attitudes and behaviours toward reading using children's literature (Doctoral dissertation, The Union Institute, Ohio, United States). Retrieved from https://www.proquest.com/products-services/dissertations/

Erdem, Mustafa. (2016). Literature in English language teaching. European Journal of Language and Literature Studies, 2(1), 157-162. doi: 10.26417/ejls.v4i1.p157-162

Gholson. R., Stumph. A.C. (2005). Folklore, literature, ethnography, and second language aqcuisition: Teaching culture in ESL classroom. TESL Canada Journal 22(22).7591. doi:10.18806/tesl.v22i2.88

Ghosn, I. (2002). Four good reasons to use literature in primary school ELT. ELT Journal, 56, (2), 172-179. doi:10.1093/elt/56.2.172

Goh, L. (1996). Using my folktales, and fairy tales in the adult ESL classroom (Thesis, Simon Fraser University, British Columbia, Canada). Retrieved from https://core.ac.uk/download/pdf/56371372.pdf 
Hasan (2019). Students' Perception towards Literature Integration in the English Language Departments at Duhok and Zakho Universities. Advances in Language and Literary Studies, 10(4), 130-152. Retrieved from https://www.journals.aiac.org.au/index.php/

Harmer, Jeremy. (2001). The Practice of English Language Teaching (3rd Edition). London: Longman

Ho, L. (2000). Children's Literature in Adult Education. Children's Literature in Education, 31(4), 259-271. doi:10.1023/A:1026431003032

Hişmanoğlu, Murat. (2005). Teaching English through literature. Journal of Language and Linguistic Studies, 1(1), 53-66. Retrieved from https://www.jlls.org/index.php/jlls/article/view/6/7/

Hutchinson, T and Waters, A. (1987). English For Specific Purpose. Cambridge: Cambridge University Press.

Ismail, I. (2019). The impact of interactive reading using local folktales stories in supporting students' vocabulary achievement in indonesian EFL learners. Majesty Journal, 1(2), 25-37. doi:10.33487/majesty.v1i2.119

Keshavarzi, Abdollah. (2012). Use of Literature in Teaching English. Procedia - Social and Behavioral Sciences, 46, 554 - 559. doi: 10.1016/j.sbspro.2012.05.159

Khodabakhshi, S. C., \& Lagos, D. C. (1993). Reading aloud: Children's literature in college ESL classes. The Journal of the Imagination in Language Learning and Teaching, 1, 53-55. Retrieved from http://coreilimagination.com/Books/V1.pdf\#page=55

Shazu, I. R. (2014). Use of literature in language teaching and learning: a Critical assessment. International Journal of African and Asian Studies - An Open Access International Journal, 5(61), 61-66. Retrieved from https://iiste.org/Journals/index.php/JAAS/article/view/12079/12419

Subhan, Bustami. (2006). Understanding literary appreciation. Yogyakarta: LPPDMF.

Viswanath, K., Mohanty. S. (2019). Tribal folklore as ELT material for first-generation learners. Advances in Language and Literary Studies, 10(2). 19-26 doi:10.5054/tj.2011.259957

Wellek, R and Warren, A. (1995). Theory of literature. New York: Harcourt, Brace, and World, Inc.

Wu, Y. (2001). English language teaching in China: Trends and challenges. TESOL Quarterly, 35(1), 191-194. doi: 10.2307/3587867

Yadav, Shalini. (2014). Recognizing the importance of literature and integration in ELT classes. International Journal of Education and Research, 2(9),393-400. Retrieved from https://www.ijern.com/journal/2014/September-2014/34.pdf 